\section{O Classics Pedagogy in the Twenty-First Century: Technology}

\section{Andrew Reinhard}

In lieu of an abstract, here is a brief excerpt of the content:

$$
\begin{aligned}
& \text { Classics Pedagogy in the Twenty- } \\
& \text { First Century: } \\
& \text { Technology }
\end{aligned}
$$

\section{Andrew Reinhard}

Technology and teaching is nothing new, even for classics, but there has yet to be any standardized approach to teaching the teachers what technology to use and how to use it. It is still very much every-teacherfor-himself-or-herself when it comes to selecting what technology to deploy in a classroom setting. For those readers actively teaching Latin and/or Greek at any level, this paper will serve as an introduction to free technologies that are actively used by your colleagues, and to online networks of peers who have already incorporated digital resources in class. It will also define strategies as you adopt one or more of these for your own courses. For readers currently enrolled in graduate programs for teaching Classical languages, this paper will show what is available digitally for teaching while encouraging both creativity and discretion in implementing these tools and games for the first time.

As you consider using technology in your classes, you should evaluate your students' (and your own) technology IQ prior to introducing technology into lessons. Find common ground and a shared comfort level in what you think will work, be it something as simple as using PowerPoint slides to recording Latin pronunciation to share on your course management system, to creating and sharing Latin questions on spaces like Quia.com. Having a shared level of technical vocabulary will prevent technology from getting in the way of teaching and learning; technology can facilitate it. Make absolutely sure you know how something works before rolling it out in class; the last thing you need is to waste precious class minutes dealing with technical issues instead of actively using technology in class. Exploring technology during the course of Latin teacher training will help prevent these kinds of missteps from happening, or at least will prepare teachers for what to do in the event of a technical glitch.

Once you have determined your own level of technical literacy and that of your students, you can begin to suggest and implement technology in your courses to reach different kinds of learners, or to work different sets of language "muscles." Different students respond differently to modec of $I$ atin inctrmetion rancine from readinc/tranclatine If you would like to authenticate using a different subscribed institution that supports Shibboleth authentication or have your own login and password to Project MUSE, click 'Authenticate'.
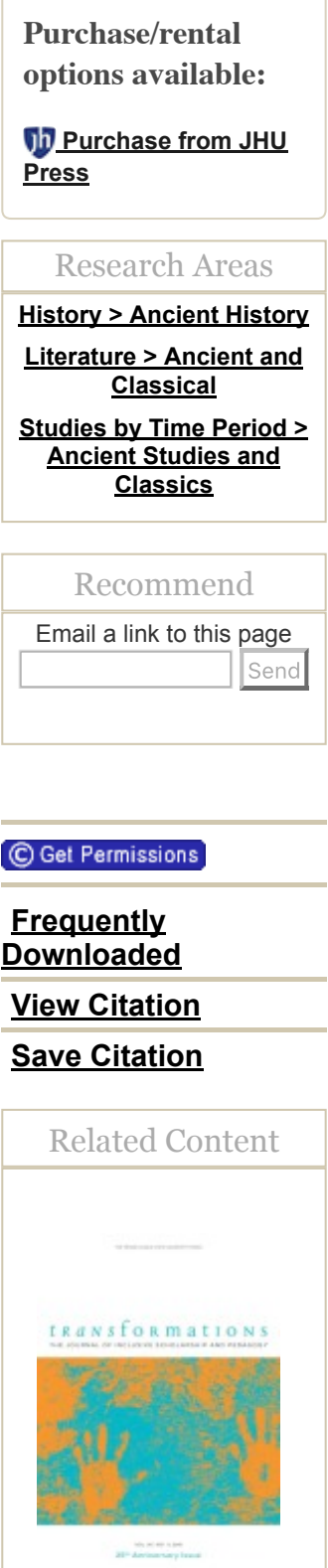

Digital Storytelling: Using Producer's Commentary in the Classroom

You are not currently authenticated.

View freely available titles: Book titles $O R$ Journal titles 
It is perhaps of foremost importance to understand that, even though the media have changed (and will keep changing), the Latin language remains the same, and the goals of teaching the language remain largely unchanged. Students still enjoy competitive board-work, games, and creative composition, being able to inject some fun into review while attempting to attain a level of proficiency with the language. Now teachers are able to use technology for these tasks as their students employ everything from YouTube to Skype to computer games to augment their traditional Latin education.

Because of the increased daily presence of technology in the lives of students (and many of their teachers), it is important for instructors to keep current with technological literacy. One needs to know what is being used by students between classes - for education and for entertainment - in order to create a menu of choices to offer students for studying, reading, and practice both on- and off-line. Open up these avenues for student projects to give the students space for creativity and flexibility within a rubric that you create. This technological openness should be mandatory for any teacher at any level, and by incorporating technology into the Latin classroom, it helps to hold students' (and teachers') interest, and keeps Latin competitive with "modern" languages, helping to improve enrollment and retention numbers.

For teachers new to modern technology, especially in the current era of do-it-yourself (DIY) entertainment (self-created music and movies posted online), it is conceivably daunting and discouraging to try to gain a quick understanding of how students can merge pop culture, technology, and Latin together for a rewarding educational experience. The best thing to do is to reach out to those teachers...

If you would like to authenticate using a different subscribed institution that supports Shibboleth authentication or have your own login and password to Project MUSE, click 'Authenticate'.

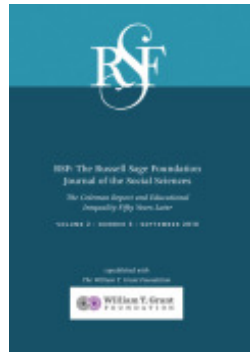

Can Technology Help Promote Equality of Educational Opportunities?

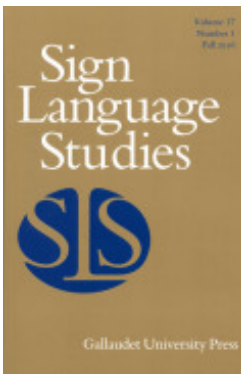

Deaf History, Digital Technology, and Content-Area

Literacy: Instructional Strategies for Secondary Classrooms

You have access to this content

Free sample

Open Access

Restricted Access 
to teach this subject matter to undergraduates or at the secondary-school kvel. Teachers can further ask students to investigate what materiak are available fors went into their chooces. If I had been asked to conduct such an investigation and to write this kind of critique. I would likely have made better choices wher I ordered books for my own lirst clases.

\section{BOLCHAZYCARDUCCI PUBUSHERS} Lanie boldhazy. com

Classics Pedagogy in the Twenty-First Century: Technology ANDREW REINHARD

Technology and teaching is nothing new, even for classics, but there has yet to be any standardbed approach to teaching the teachers what technology to use and how to use it. It is still very much every-teacher for-himselfor the rself when it comes to selecting what technology to depboy in a class room setting. For those readers actively teaching Latin and/or Greek at any kvel, this paper will serve as an introduction to free technologies that are actively used by your colleagues. and to online networks of peens who have already hoorporated digital resouroes in class. It will a bo define strategles as you adopt one or more of these for your own courses. For readers curtenily enforkd in graduate programs for teaching Classical languages, this paper will show what is available digially for teaching while encouraging both creativity and discre tion in implementing these tools and games for the first time.

As you consider using technology in your chsses, you should evaluate your students' (and your own) lecthology IO prior to introducing lectinology into lessons. Find commont ground and a stared comfart kevel in what you think will work, be in sometting as simple as wsing powetpoint stides to tecording

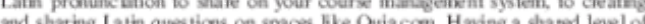

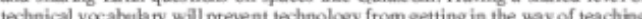

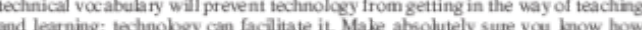
scmething work before rolling it out in chas: the last thing you toed is 10 wow precious chas minutes dealing with technical issues instead of actueby using precthology in class, Exploring technology during the course of Latin teacher uainiaguill help prevent these kinds of misteps from happening or a 1 kast will

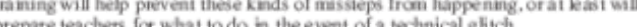
prepure teachers lor what to do in the event of a technical glitch. of your students, you can begin to suggest and implement tectuology in your courses to reach different kinds of ba mers, or to wotk different sets of hanguage "muscles." Different students respond differently to modes of Latin instruction ranging from reading/transhating to original composition to oral/aural practice. Consider using all of these appronches throughout each semester to add variety to Latin education via technologs, mirforing traditional teaching methods with new media.

\section{Welcome to Project MUSE}

Use the simple Search box at the top of the page or the Advanced Search linked from the top of the page to find book and journal content. Refine results with the filtering options on the left side of the Advanced Search page or on your search results page. Click the Browse box to see a selection of books and journals by: Research Area, Titles A-Z, Publisher, Books only, or Journals only.

\section{Connect with Project MUSE}

Join our Facebook Page

Follow us on Twitter

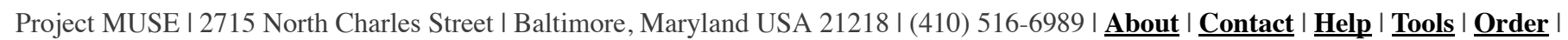
Accessibility

(C)2017 Project MUSE. Produced by The Johns Hopkins University Press in collaboration with The Milton S. Eisenhower Library.

If you would like to authenticate using a different subscribed institution that supports Shibboleth authentication or have your own login and password

to Project MUSE, click 'Authenticate'.
You are not currently authenticated.

AUTHENTICATE
View freely available titles: Book titles OR Journal titles 